\title{
PENTAD ANALISIS PADA FILM LEGEND OF THE GUARDIANS
}

\author{
Latifah Novitasari, Prayudi, dan Agung Prabowo
}

\author{
Program Studi Ilmu Komunikasi FISIP UPN “Veteran” Yogyakarta, Jl. Babarsari No. 2, \\ Tambakbayan Yogyakarta, No. Hp. 085229829171 \\ Email : latifnovi1425@gmail.com
}

\begin{abstract}
The research aims to analyze representation of heroism value in the Legend Of The Guardians: The Owls Of Ga'hoole movie by using dramatism theory as the main theory and pentad analysis as a method. The results showed that the representation of the heroism value in the Legend Of The Guardians: The Owls Of Ga'Hoole movie indicated by drawing the five elements pentad consist of, act always includes scenes battle to save his kingdom. Scene is indicated by the use low key lighting concept to give the impression of dramatic, suspenseful and gripping the battle scenes in the movie. Agent illustrated with heroic character, never give up, willing to sacrifice, to protect the weak and defend the truth which is represented through the character Soren, Digger, Twillight, Gylfie and the Guardians. Agency displayed using war and believe gizzard activity in achieving a specific goal, and the last purpose shown by figures eradicate evil creatures in order to save the oppressed and restore peace to the kingdom of owls are great $\mathrm{Ga}$ 'Hoole tree.
\end{abstract}

Keywords: pentad analysis, dramatism, movie, heroism

\begin{abstract}
Abstrak
Penelitian ini bertujuan menganalisis representasi nilai-nilai kepahlawanan dalam film Legend Of The Guardians: The Owls Of Ga'hoole. Teori dramatisme sebagai acuan dengan metode penelitian pentad analysis. Hasil penelitian menunjukkan bahwa representasi nilai kepahlawanan dalam film Legend Of The Guardians: The Owls Of Ga'hoole ditunjukkan pada lima unsur pentad yang terdiri dari, act yang selalu menonjolkan adegan peperangan untuk menyelamatkan kerajaannya. Scene ditunjukkan dengan penggunaan konsep low key lighting untuk memberikan kesan dramatis, menegangkan dan mencekam pada adegan peperangan dalam film tersebut. Agent digambarkan dengan karakter gagah berani, pantang menyerah, rela berkorban, melindungi yang lemah, dan membela kebenaran yang diwakilkan melalui tokoh Soren, Digger, Twillight, Gylfie dan para Guardians. Agency ditampilkan dengan menggunakan kegiatan peperangan dan mempercayai gizzard dalam mencapai sebuah tujuan tertentu, dan yang terakhir purpose ditampilkan dengan tokoh yang membasmi kejahatan demi menyelamatkan makhluk yang tertindas serta mengembalikan kedamaian kerajaan burung hantu yang berada di pohon besar Ga'hoole.
\end{abstract}

Kata kunci: analisis pentad, dramatisme, film, kepahlawanan.

\section{Pendahuluan}

Film merupakan karya seni yang diproduksi pada era modern seperti ini. Sebagai objek seni abad ini, film mulai menjadi salah satu unsur yang melekat pada kehidupan sosial dan tentunya, memberikan dampak yang cukup signifikan bagi para penontonnya. Melalui media film seorang sutradara menyalurkan informasi, pesan moral, nilainilai kepahlawanan, nilai sosial maupun pemikiran-pemikiran kreatifnya kepada audiens yang dituju, dengan harapan sebuah film tersebut mampu mengedukasi audiensnya atau bahkan mampu merubah perilaku dan sikap dari audiensnya.

Munculnya berbagai film animasi 3D seperti Open Season (2006), Toy Story 3 (2010), Legend of The Guardians : The Owls Of Ga'hoole (2010), Alvin And The Chipmunks: Chipwrecked (2011), Cars 2 (2011), The Smurfs (2011), dan juga Gnomeo And Juliet (2011) ini memperlihatkan bahwa betapa majunya dunia perfilman di Amerika sehingga dijadikan sebagai kiblat bagi dunia perfilman yang lain. Film Legend Of The Guardians : The Owls Of $G a^{\prime}$ hoole ini mengangkat cerita fantasi 
yang bertemakan kepahlawanan. Film yang disutradarai oleh Zack Snyder dan diproduksi oleh Warner Bros Pictures tersebut secara khusus menceritakan tentang petualangan Soren bersama tiga temannya untuk menyelamatkan kerajaan burung hantu dari serangan The Pure Ones yang diketuai oleh Metalbeak.

Pahlawan sering diartikan sebagai seseorang yang mempunyai jiwa berani, tangguh, pantang menyerah, jujur, berani, bertanggungjawab serta mau berkorban demi kepentingan bersama. Definisi kepahlawanan ini tergambar dalam beberapa adegan yang ada dalam film Legend Of Guardians : The Owls Of Ga'hoole. Sehingga film ini mempunyai kaitan yang erat dengan rumusan masalah penelitian yang akan dilakukan yaitu bagaimana representasi nilai-nilai kepahlawanan dalam film Legend Of Guardians : The Owls Of Ga'hoole?.

Melalui studi dramatisme dengan metode pentad analysis, peneliti ingin mengetahui nilai-nilai kepahlawanan dan makna yang tersirat dalam Film Legend of The Guardians : The Owls of Ga'hoole karya Zack Snyder. Bagian utama dari studi dramatisme adalah terpusat pada manusia, di dalam teori dramatisme manusia merupakan makhluk yang menggunakan simbol. Dengan simbol manusia mampu melakukan refleksi, representasi, seleksi dan juga defleksi (pembelokan) terhadap realitas (Suparno, 2011:187). Manusia adalah makhluk yang mempunyai sifat, sikap maupun pemikiran yang beraneka ragam dan salah satunya adalah manusia memiliki sifat kepahlawanan. Sifat kepahlawanan yang dimiliki manusia ini ditunjukkan melalui perwakilan karakter dengan menggunakan animasi burung hantu sebagai tokoh-tokohnya lewat film Legend Of Guardians: The Owls Of $\mathrm{Ga}$ 'hoole.Dramatisme, sebagaimana terlihat dari namanya, mengonseptualisasikan kehidupan sebagai sebuah drama, menempatkan suatu fokus kritik pada adegan yang diperlihatkan oleh berbagai pemain. Dramatisme memberikan sebuah metode yang sesuai untuk membahas tindakan komunikasi antara teks dan khalayak untuk teks, serta tindakan di dalam teks itu sendiri. Sebagaimana dikatakan oleh C.Roland Kimberling bahwa Dramatisme secara menyakinkan memberikan sebuah pandangan kritis yang tidak dapat dihasilkan oleh metode lainnya (West and Turner, 2010:26). Drama adalah metafora yang berguna bagi ideide Burke untuk tiga alasan: (1) Drama mengindikasikan cakupan yang luas, dan Burke tidak membuat klaim yang terbatas; tujuannya adalah untuk berteori mengenai keseluruhan mengenai pengalaman manusia. Metafora dramatis khususnya berguna dalammenggambarkanhubungan manusia karena didasarkan pada interaksi atau dialog. Dalam dialognya, drama menjadi model hubungan dan juga memberikan penerangan pada hubungan.

(2) Drama cenderung untuk mengikuti tipe-tipe atau genre yang mudah dikenali; komedi, musikal, melodrama, dan lainnya. Burke merasa bahwa cara kita membentuk dan menggunakan bahasa yang dapat berhubungan dengan cara drama manusia ini dimainkan. (3) Drama selalu ditujukan pada khalayak. Dalam hal ini, drama bersifat retoris. Burke memandang sastra sebagai "peralatan untuk hidup," artinya bahwa literatur atau teks berbicara pada pengalaman hidup orang dan masalah serta memberikan orang reaksi untuk menghadapi pengalaman ini. Dengan demikian, kajian Dramatisme mempelajari cara-cara bahasa dan penggunaannya berhubungan dengan khalayak (West and Turner, 2010: 27).

TeoriBurketersebutmembandingkan kehidupan dengan sebuah pertunjukan dan menyatakan bahwa, sebagaimana dalam sebuah karya teaterikal, kehidupan membutuhkan adanya seorang aktor, 
sebuah adegan, beberapa alat untuk terjadi adegan itu, dan sebuah tujuan.

Brummett memberikan gambaran mengenai tiga asumsi teori dramatisme Burke berikut ini: (1) Manusia adalah hewan yang menggunakan simbol. (2) Bahasa dan simbol membentuk sebuah sistem yang sangat penting bagi manusia. (3) Manusia adalah pembuat pilihan (West and Turner, 2010:27-28). Menurut Porwodarminto, makna patriotisme atau kepahlawanan mempunyai keterkaitan dengan perjuangan yaitu dua atau lebih kekuatan dan kekuasaan yang saling berbeturan dalam upaya memperebutkan sesuatu.Dengan katalain ialah perbuatan sesuatu antara dua atau lebih kekuatan dan kekuasaan dengan saling mengadu tenaga masing-masing yang dimiliki. Perjuangan juga diasosiasikan atau dimaknai sebagai sesuatu perkelahian (fight) atau peperangan (combat) (Surata dan Andrianto, 2003: 263-264).

Pahlawan sering diartikan sebagai seseorang yang mempunyai jiwa yang berani, tangguh, pantang menyerah, dan mau berkorban untuk kepentingan bersama. Tokoh bisa dikatakan sebagai pahlawan jika mempunyai jiwa patriotisme dan jiwa satria. Jiwa patriotisme menurut kamus besar bahasa indonesia adalah sikap seseorang yang bersedia mengorbankan segala-galanya untuk kejayaan dan kemakmuran tanah airnya. Kriteria jiwa patriotisme ini meliputi, cinta damai, ikhlas berkorban, mengutamakan kepentingan nasional daripada kepentingan pribadi dan golongan, bertanggungjawab dan pantang menyerah, serta gagah berani (Surata dan Andrianto, 2003: 268).

Dalam kamus besar bahasa Indonesia jiwa satria atau sering disebut kesatria berarti sikap seseorang yang pemberani, pembela kebenaran, penegak keadilan dan pelindung bagi yang lemah. Kriteria jiwa satria ini meliputi, sederhana, ulet, tabah, berpendirian teguh, menghargai, melindungi yang lemah, membela kejujuran, kebenaran dan keadilan, bijaksana dan mempunyai rasa senasib sepenanggungan (Surata dan Andrianto, 2003: 269).

\section{Metode Penelitian}

Penelitian menenai pentad anaylisis ini menggunakan pendekatan kualitatif yang bersifat intepretatif. Metode penelitian yang dipakai adalah metode pentad analisis dari Kenneth Burke. Burke menyebut metodenya pentad analysis karena metode ini terdiri atas lima poin untuk menganalisis teks simbolik seperti perbincangan atau serangkaian artikel. Lima poin yang menyusun pentad mencakup act, scene, agent, agency dan purpose (West and Turner, 2010: 32). Penjelasan dari kelima poin tersebut adalah sebagai berikut:

Adegan (scene) memberikan konteks yang melingkupi tindakan (West and Turner, 2010:33). Secara sederhana scene merupakan istilah yang mencakup berbagai konsep tentang latar belakang atau setting secara umum. Scene tidak lain adalah sebuah nama bagi berbagai situasi di mana agen/aktor melakukan tindakan. Scene seperti yang dikatakan Hart semacam panggung di mana para aktor menjalankan suatu adegan atau episode tindakan yang menggambarkan kondisi-kondisi masyarakat, pengaruhpengaruh sosial, sebab-sebab historis dan kejadian-kejadian atau peristiwa alamiah (Suparno, 2011: 196-198).

Agen (agent) adalah seseorang atau orang-orang yang melakukan tindakan (West and Turner, 2010:33). Di bawah istilah agen, seseorang dapat menempatkan pernak-pernik personal yang menyertai nilai motivasional seperti gagasan, keinginan, ketakutan, kedengkian, instuisi, imajinasi dan ekspresi personalitas lainnya. Melalui penjelasan ini Burke menunjukkan ciri- 
ciri yang dimiliki agen seperti ego, konsep diri, super ego, kesadaran, keinginan, objektif, pikiran, semangat dan ekspresi. Agen tidak saja dapat dipandang secara individual atau personal, tetapi dapat merupakan super person seperti gereja, ras, bangsa dan etnis misalnya (Suparno, 2011: 198-199).

Burke menganggap tindakan (act) sebagai apa yang dilakukan oleh seseorang (West and Turner, 2010: 33). Seperti yang telah disinggung bahwa konsep tindakan (act) bersumber pada dua hal yakni karakter dan pemikiran (Fergusson dalam Suparno, 2011: 199). Dramatisme menjelaskan bahwa karakter manusia mendisposisikan dirinya bertindak di dalam cara-cara tertentu, tetapi sebenarnya ia bertindak hanya dalam merespon pada lingkungan yang terus berubah. Dalam pengertian dramatistik, tindakan (act) tidak dalam arti sebagai tindak tanduk, perilaku, kejadian atau kegiatan fisik, melainkan adalah motivasi tindakan yang bersumber dari motifmotif. Tindakan manusia itu sendiri pada umumnya terdiri dari tiga bentuk, yakni praxis, poeisis dan theoria. Representasi tindakan itu sendiri tidak dapat dilepaskan dari aspek bahasa di dalam drama (Suparno, 2011:199-200).

Agensi (agency) merujuk pada caracara yang digunakan oleh agen untuk menyelesaikan tindakan. Bentuk-bentuk agensi yang mungkin mencakup strategi pesan, penceritaan kisah, permintaan maaf, pembuatan pidato dan seterusnya (West and Turner, 2010: 33). Dalam pemikiran dramatisme, yang dimaksud dengan agency adalah instrument yang digunakan manusia untuk mencapai tujuan (Suparno, 2011: 200).

Tujuan atau (purpose) merujuk pada hasil akhir yang ada dalam benak agen untuk tindakan yaitu mengapa tindakan dilakukan (West and Turner, 2010: 33). Dalam hubungan dengan tujuan (purpose), maka agency merupakan fungsi dari tujuan. Dengan keterangan ini, jelas terlihat bahwa hubungan antara agency dan purpose merupakan hubungan yang mendasarkan pada prinsipprinsip kegunaan dan prinsip-prinsip keinginan. Dengan kata lain, agency menstransendensikan tujuan. Melalui prinsip-prinsip kegunaan, bahasa dapat dipandang sebagai agency yang digunakan untuk menstransendensikan tujuan (Suparno, 2011: 200-201).

\section{Hasil Penelitian dan Pembahasan}

Sinopsis Film Legend Of The Guardians

Film Legend Of The Guardians : The Owls Of Ga'hoole ini menceritakan tentang si kecil Kludd, Soren dan Eglantine yang selalu mendengarkan dongeng dari sang ayah sebelum mereka beranjak tidur. Dongeng yang selalu mereka dengarkan mengisahkan tentang The Guardians yang hidup di pohon besar Ga'Hoole. The Guardians adalah pahlawan yang melawan Metalbeak dan menjaga kerajaan burung hantu dari ancaman The Pure Ones, dan dari sinilah Soren dan Eglantine mulai mengidolakan para Guardians. Mereka menganggap bahwa para Guardians itu benar-benar ada di kehidupan nyata, tetapi Kludd sang kakak tak sependapat dengan adik-adiknya, ia mengganggap itu semua hanyalah kebohongan dan imajinasi semata. Pada kenyataannya, The Guardians yang tinggal di pohon besar Ga'Hoole dan juga The Pures Ones yang dipimpin oleh Metalbeak memang benar adanya di kehidupan nyata mereka.

Hasil penelitian pentad analysis secara interpretatif menemukan adanya nilai-nilai kepahlawanan dalam film Legend Of The Guardians. Pahlawan sering diartikan sebagai seseorang yang mempunyai jiwa yang berani, tangguh, pantang menyerah, dan mau berkorban untuk kepentingan bersama. Tokoh dalam 
film bisa dikatakan sebagai pahlawan jika mempunyai jiwa patriotisme dan jiwa satria. Nilai kepahlawanan yang tergambar dalam film ini terjadi dengan bentuk jiwa patriotisme yang meliputi: (1) gagah berani; (2) rela berkorban; dan (3) pantang menyerah; serta tergambar dalam bentuk jiwa satria yang meliputi: (1) melindungi yang lemah; (2) membela kebenaran; dan (3) rasa senasib sepenanggungan.

\section{Jiwa Patriotisme}

Dalam film Legend Of The Guardians hal itu terlihat dari banyaknya adegan yang menampilkan nilai-nilai kepahlawanan, misalnya pada adegan jiwa patriotisme dengan parameter gagah berani. Gagah berani menurut kamus besar bahasa Indonesia mempunyai arti sangat pemberani, perkasa dan kuat. Adegan yang menggambarkan gagah berani dalam film ini ditunjukkan dalam scene berikut ini:

Sesuai dengan teknik analisa data pentad analysis penggambaran sifat gagah berani dalam gambar 1. ditunjukkan dengan act atau tindakan Soren yang sedang menyelamatkan Kludd dari serangan hewan buas. Dengan didukung teknik pengambilan gambar high angle kolaborasi over shoulder shot pada adegan Kludd diterkam hewan buas memberikan efek tertindas dan lemah pada Kludd. Akhirnya Soren mencoba melawan hewan buas itu dengan menggigit telinga

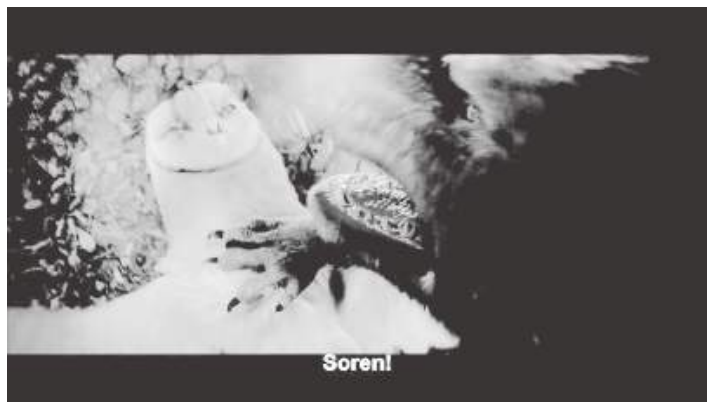

Gambar 1. Soren menyelamatkan Kludd dari serangan hewan buas

(sumber: data primer) dan mengepakkan kedua sayapnya tepat dimuka hewan buas tersebut. Teknik pengambilan gambar yang digunakan pada adegan tersebut adalah medium shot. Teknik ini menampilkan dua tokoh yaitu Soren dan hewan buas yang bertarung dengan ekspresi wajah yang sangat garang. Dengan adanya teknik ini mendukung tindakan kepahlawanan yaitu gagah berani yang dimiliki oleh Soren. Tindakan gagah berani yang dilakukan Soren ini pada dasarnya adalah dilatarbelakangi oleh keinginan Soren yang ingin menjadi seperti sang idola yaitu Lyze Of Kiel. Soren begitu mengidolakan pahlawannya hingga ia mau melakukan apa saja agar bisa terlihat seperti idolanya. Bahkan Soren tak memperdulikan keselamatannya hanya untuk menyelamatkan kakaknya. Dari sinilah muncul suatu gambaran sifat kepahlawanan gagah berani melalui karakter tokoh Soren. Untuk menampilkan gambaran gagah berani secara utuh dalam adegan ini maka, penggambaran tersebut di dukung oleh unsur lain yakni, scene atau setting.

Unsur scene atau setting dari penggalan adegan di atas adalah saat malam hari tiba Soren dan Kludd terjatuh dari sarangnya ketika melakukan percabangan. Sarang mereka berada di hutan tyto yang sepi dan sunyi. Bagi burung hantu, berada dibawah sarang adalah sebuah pantangan yang harus dihindari, karena menurut mereka berada di tanah adalah tempat terburuk untuk semua burung hantu. Hal ini ditunjukkan dengan dialog Kludd yang menyatakan bahwa "Oh, tidak, kita tidak boleh berada disini. Ini adalah tempat terburuk bagi semua burung hantu". Dari penjelasan dialog tersebut dapat dimaknai sebagai informasi yang menyatakan bahwa burung hantu yang masih kecil tidak boleh meninggalkan sarangnya karena, mereka belum mempunyai cakar yang kuat dan belum bisa terbang 
dengan sempurna. Sehingga burung hantu tersebut bisa dijadikan mangsa oleh predator lainnya. Selain itu burung hantu jenis tyto atau sering disebut burung hantu serak jawa, seperti yang digambarkan oleh karakter Soren dan Kludd ini memang habitatnya berada di atas pohon sehingga mereka jarang sekali berada di tanah kecuali menangkap mangsanya (http:// raptorclubIndonesia.or.id).

Setting pada malam hari ini menjelaskan bahwa kehidupan burung hantu adalah dimalam hari. Burung hantu pada dasarnya merupakan spesies burung pemangsa yang aktif pada malam hari atau nokturnral. Sebagaian besar burung hantu melakukan perburuan atau mencari mangsa hingga berlatih percabangan adalah ketika malam tiba (http:// raptorclubIndonesia.or.id). Sehingga setting ini secara tidak langsung menampilkan sisi kehidupan burung hantu yang ada dikehidupan nyata. Penggunaan konsep low key lighting pada adegan tersebut memberikan kesan suasana yang mencekam dan menyeramkan. Suasana ini semakin mendukung ekspresi dari Soren dan Kludd yang ketakutan ketika berada dibawah pohon. Munculnya rasa takut dari kedua burung hantu tersebut dikarenakan mereka belum bisa terbang dengan sempurna dan dikejar oleh hewan buas.

Penggambaran jiwa gagah berani juga akan semakin kuat jika didukung oleh unsur agent yang ada dalam adegan tersebut. Agent adalah aktor yang menampilkan adegan. Dalam penggalan adegan di atas aktor yang bertindak menyelamatkan Kludd adalah Soren. Soren merupakan adik Kludd yang mempunyai sifat pemberani dan tangguh. Hal ini ditunjukkan dengan tindakannya yang berani melawan hewan buas demi menyelamatakan kakaknya. Soren tak peduli dengan keselamatannya yang penting kakaknya bisa selamat dari serangan hewan buas tersebut. Jiwa gagah berani yang dimiliki oleh Soren ini sudah muncul dan terbentuk sejak ayahnya selalu bercerita kepadanya tentang perjuangan Lyze Of Kiel dalam membasmi kejahatan. Berbeda halnya dengan Kludd, Kludd adalah sosok burung hantu yang egois dan pengecut. Kludd hanya memikirkan keselamatan dirinya sendiri dan tidak memikirkan keselamatan adiknya. Hal ini tergambar dalam adegan ketika Soren sedang bertarung dengan hewan buas, Kludd langsung melarikan diri dan sembunyi dibalik pohon agar tidak terlihat hewan buas tersebut. Melalui adegan ini sang sutradara mencoba menggambarkan dua sosok burung hantu yang berbeda sifatnya yaitu si pemberani dan si egois. Aktor lain yang ada dalam adegan di atas adalah hewan buas. Hewan buas disini berbentuk seperti tikus hutan yang sedang kelaparan dan mencari mangsa ketika malam hari. Karena hewan buas ini merasa mempunyai tubuh yang lebih besar dan kuat daripada Kludd dan Soren, maka ia mengejar dan ingin memakan kedua burung hantu kecil itu.

Sifat gagah berani tidak akan muncul dalam suatu adegan tanpa adanaya unsur agency. Unsur agency ini merujuk pada cara-cara untuk mencapai tujuan. Agency dalam penggalan adegan di atas adalah Soren tak menggunakan senjata apapun untuk melawan hewan buas tersebut. Soren hanya mengandalkan dan mengerahkan seluruh keberaniannya untuk menyerang hewan buas itu. Meskipun Soren belum bisa terbang dengan sempurna, namun Soren tetap berusaha terbang untuk melawan dan menggigit telinga hewan yang menyerang Kludd. Penggambaran karakter Soren yang belum bisa terbang disini menunjukkan sebuah perjuangan seekor burung hantu kecil untuk mendapatkan tujuan tertentu yakni menyelamatkan kakaknya dan 
mengalahkan hewan buas. Karakter belum bisa terbang ini semakin menguatkan nilai kepahlawanan gagah berani pada adegan di atas, karena apabila Soren sudah bisa terbang dengan sempurna pasti tidak akan dikejar oleh hewan buas dan bisa mengalahkan hewan tersebut tanpa perjuangan yang keras.

Unsur lain yang menjadi pendukung terbentuknya sifat gagah berani dalam adegan di atas adalah adanya unsur pupose. Purpose atau tujuan yang ada dalam penggalan adegan di atas adalah Soren menyerang hewan buas tersebut untuk menyelamatkan Kludd. Soren tak ingin saudaranya terluka sehingga, ia berusaha sekuat tenaga untuk menyelamatkan kakaknya dari ancaman musuh tersebut. Meski Kludd terlalu egois dan hanya mementingkan dirinya sendiri, akan tetapi Soren tetap membantu dan menyelamatkannya. Hal ini didasari oleh sifat tolong-menolong dan rasa sayangnya kepada Kludd yang dimiliki oleh Soren. Sehingga Soren selalu membantu dalam keadaan apapun meski Kludd tak pernah memikirkan keselamatannya. Selain itu tujuan dari adegan di atas adalah untuk menunjukkan sifat kepahlawanan yang gagah berani ketika melawan musuh melalui karakter Soren.

Dari penjelasan lima unsur di atas bisa ditarik kesimpulan bahwa penggalan adegan tersebut menggambarkan nilai kepahlawanan yang gagah berani, hal ini terlihat dari adegan Soren yang menyelamatkan Kludd dari serangan hewan buas ketika mereka berdua jatuh dari sarang saat melakukan percabangan. Unsur yang paling dominan dalam menggambarkan sikap gagah berani pada penggalan adegan di atas adalah pada unsur act. Act dalam adegan tersebut sangat kuat dalam menggambarkan gagah berani, karena tindakan Soren saat melawan hewan buas demi menyelamatkan sang kakak dapat langsung diterjemahkan bahwa tokoh Soren ini mempunyai sifat yang gagah berani. Soren mempunyai badan kecil tetapi ia tetap berani melawan hewan yang lebih besar dan menyeramkan. Dengan didukung penggunaan teknik pengambilan gambar dan konsep lighting yang baik, adegan tersebut mampu menggambarkan seekor burung hantu muda yang mempunyai jiwa gagah berani dalam menyelamatkan jiwa yang lemah. Penggambaran aktor Soren yang melakukan tindakan penyelamatan terhadap Kludd dari serangan hewan buas bertujuan untuk menolong dan menyelamatkan Kludd. Agency yang digambarkan untuk mendukung sifat gagah berani adalah Soren hanya mengandalkan keberanian dalam dirinya tanpa menggunakan senjata apapun untuk melawan hewan buas itu.

\section{Jiwa Satria}

Dalam adeganlainjuga menampilkan nilai kepahlawanan misalnya pada adegan jiwa satria dengan parameter melindungi yang lemah. Menurut kamus besar bahasa Indonesia, melindungi yang lemah berarti menjaga, menyelamatkan dan memberi pertolongan kepada jiwa yang lemah dan tertindas. Sifat melindungi yang lemah dalam film ini tergambar pada beberapa adegan berikut.

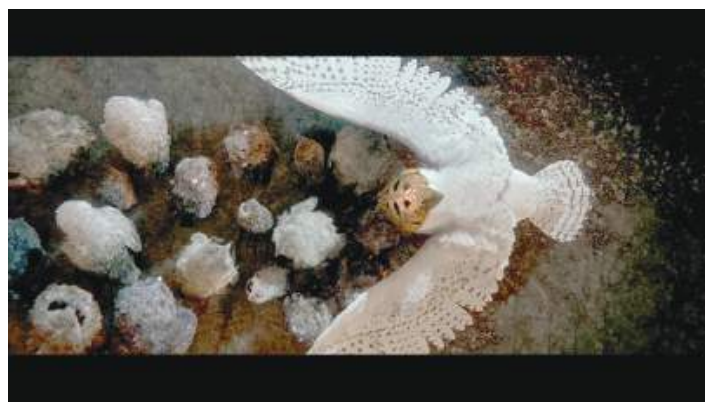

Gambar 2. Boron melindungi beberapa burung hantu kecil yang terhipnotis kedipan bulan purnama

(sumber: data primer) 
Sesuai dengan teknik analisa data pentad analysis, pada adegan pada gambar 2. dtunjukkan dengan tindakan Raja dari kerajaan burung hantu yakni Boron menyelamatkan beberapa burung hantu kecil yang terhipnotis oleh kedipan bulan purnama. Tindakan penyelamatan ini semakin terlihat jelas dan menonjol dengan didukung teknik kamera high angle yang memberikan kesan lemah dan tertindas. Boron berusaha untuk merangkul seluruh burung hantu kecil tersebut dengan meregangkan kedua sayapnya selebar mungkin. Hal tersebut semakin menguatkan bahwa adegan ini menunjukkan melindungi yang lemah. Ironisnya keinginannya untuk melindungi yang lemah bahkan membuat Boron tidak menyadari jika dirinya sedang di jebak.

Unsur pentad yang lain ditunjukkan melalui Scene. Dalam adegan di atas sang Raja menyelamatkan burung-burung yang ditawan oleh The Pure Ones di St. Aegolius saat malam hari tiba. Setting yang digambarkan pada adegan ini adalah di medan pertempuran dengan suasana yang mencekam, menegangkan dan sunyi. Burung-burung yang ditawan oleh The Pure Ones keadaannya sangat memilukan, dalam keadaan terhipnotis karena terkena kedipan bulan purnama yang akhirnya membuat mereka tidak sadarkan diri. Keadaan para tawanan ini menggambarkan keberhasilan The Pure Ones untuk menjebak para Guardians. Dengan penggunaan konsep low key lighting semua suasana itu mampu tergambar dalam adegan tersebut.

Dari adegan tersebut dapat dianalisa Agent yang ditampilkan yakni sang Raja dari kerajaan burung hantu yaitu Boron berusaha melindungi dan menyelamatkan burung hantu kecil dari kejahatan The Pure Ones. Sang Raja mempunyai sifat kepahlawanan yakni melindungi dan menyelamatkan yang lemah seperti sumpahnya yang dijunjung tinggi yaitu menguatkan yang lemah dan memperbaiki yang rusak. Agent yang lain ditunjukkan oleh burung-burung hantu kecil yang ditawan oleh The Pure Ones. Burung-burung tersebut dijadikan umpan untuk menjebak Guardians agar masuk dalam perangkap The Pure Ones.

Untuk mengetahui metode-metode yang digunakan maka adegan tersebut dianalisa menggunakan unsur Agency yang ditunjukkan oleh tindakan sang Raja menggunakan sayapnya untuk merangkul dan melindungi semua burung hantu kecil tersebut dari kejahatan The Pure Ones. Sang Raja menggunakan seluruh keyakinan dan kekuatannya untuk melindungi dan menguatkan mereka yang lemah. Di sisi lain The Pure Ones memiliki metode untuk menggunakan burung-burung hantu kecil tawanan nya sebagai umpan untuk menjebak Guardians.

Pada adegan tersebut juga dapat dijabarkan Purpose dari sang Raja yaitu berusaha menyelamatkan dan melindungi burung hantu yang lemah dari kejahatan The Pure Ones. Sang Raja tak ingin komunitasnya yang masih muda dan lemah ini menjadi korban dari kejahatan yang dilakukan The Pure Ones. Selayaknya seorang pemimpin, sang Raja tetap berusaha sekuat tenaga untuk melindungi yang lemah dan menjaganya dari segala hal yang dapat mengancam keselamatan komunitasnya maka The Pure Ones mempunyai tujuan untuk menjebak para Guardians dengan menggunakan burung-burung hantu tawanannya. Hal ini dilakukan karena The Pure Ones ingin menghancurkan Guardians dan memperluas daerah kekuasaanya.

Sesuai dengan penjelasan lima unsur pentad di atas dapat disimpulkan bahwa adegan tersebut menggambarkan tentang sifat kepahlawanan yakni melindungi 
yang lemah. Hal ini ditunjukkan dengan tindakan penyelamatan yang dilakukan oleh sang Raja ketika berusaha menyelamatkan dan melindungi semua burung hantu kecil dari kejahatan The Pure Ones. Unsur yang paling dominan dalam menggambarkan sifat melindungi yang lemah adalah terletak pada scene. Penggambaran scene dengan menggunakan teknik high angle, slow motion dan juga konsep low key lighting membuat sifat melindungi yang lemah semakin kuat karena teknik-teknik tersebut memberikan kesan yang dramatis, ironis dan menampilkan sosok makhluk yang tertindas secara jelas sehingga adegan penyelamatan yang dilakukan oleh Boron dapat segera dimaknai sebagai sifat melindungi yang lemah.

Film Legend Of Guardians: The Owls Of Ga'hoole merupakan film yang mengangkat tema kepahlawanan serta perjuangan memberantas kejahatan demi mewujudkan kerajaan yang aman, tentram dan sejahtera. Secara umum film Legend Of Guardians: The Owls of Ga'hoole memperlihatkan bahwa nilainilai kepahlawanan sangat dibutuhkan untuk mencapai suatu kehidupan yang aman, tentram dan sejahtera, meski harus mengorbankan nyawa. Film adalah medium komunikasi massa, yaitu alat penyampai berbagai jenis pesan dalam peradaban modern ini seperti dalam film Legend Of Guardians: The Owls Of Ga'hoole ini. Film tersebut menyampaikan pesan kepahlawanan kepada audiensnya. Bentuk-bentuk pesan kepahlawanan ini dikemas rapi dan indah dengan menggunakan teknik-teknik sinematografi yang baik dan teknologi yang modern. Setelah melakukan interpretasi dengan menggunakan pentad analysis pada film Legend Of Guardians: The Owls Of Ga'hoole dapat disimpulkan bahwa, bentuk-bentuk nilai kepahlwanan yang ditonjolkan meliputi gagah berani, pantang menyerah, rela berkorban, membela kebenaran, melindungi yang lemah dan senasib sepenanggungan. Perwujudan dari nilainilai kepahlawanan diatas ditampilkan dengan penggambaran act yang selalu ditonjolkan dengan peperangan diantara tokoh-tokohnya. Tindakan ini dilakukan untuk membasmi kejahatan dan mengembalikan kedamaian serta kesejahteraan kelompoknya. Hal ini ditunjukkan dari beberapa adegan yang selalu menampilkan peperangan untuk menegakkan keadilan.

Misalnya, seperti adegan peperangan antara Soren dan Metalbeak untuk menyelamatkan Lyze of Kiel. Adegan lain yang menampilkan peperangan untuk mendapatkan suatu tujuan adalah adegan Soren berperang melawan hewan buas untuk menyelamatkan Kludd. Penggambaran nilai-nilai kepahlawanan juga didukung dengan scene yang selalu menggunakan konsep low key lighting dan slow motion untuk memberikan kesan dramatis, menegangkan dan mencekam pada adegan peperangan yang dilakukan oleh tokoh-tokoh dalam film tersebut. Dalam film Legend of The Guardians: The Owls of Ga'hoole ini kebanyakan menggunakan konsep low key lighting karena memang setting yang digunakan adalah sesuai dengan kehidupan asli burung hantu yaitu ketika malam hari. Konsep low key lighting dengan kolaborasi slow motion juga semakin memperkuat penggambaran nilai-nilai kepahlawanan ketika ditampilkan pada adegan dengan setting peperangan atau medan pertempuran. Teknik ini misalnya digunakan pada saat menampilkan adegan Soren terbang melintasi api dengan membawa cawan di kakinya untuk menyelamatkan Guardians yang terjebak dalam aliran magnet. Dengan penggunaan kolaborasi teknik medium 
close up, konsep low key lighting dan juga slow motion pada adegan Soren melintasi api tersebut memberikan kesan pengorbanan dan perjuangan yang sangat dramatis yang membuat penonton bisa hanyut dan merasakan dalam suasana tersebut.

Selain itu nilai kepahlawanan juga digambarkan dengan penggunaan agent atau aktor yang mempunyai karakter gagah berani, pantang menyerah, rela berkorban, melindungi yang lemah, dan membela kebenaran yang diwakilkan melalui tokoh Soren, Digger, Twillight, Gylfie dan para Guardians seperti Boron, Lyze of Kiel, Bubo, Otulissa serta Guardians lainnya. Karakter animasi yang dibuat pun menunjukkan wajah yang sederhana, bijaksana, lembut, dan baik hati. Tak hanya tiga unsur diatas saja namun, penggambaran nilai kepahlawanan juga didukung dengan agency yang digunakan oleh para tokoh dalam membasmi kejahatan.

Bentuk agency ini ditampilkan dengan menggunakan kegiatan peperangan yang dilakukanoleh para tokohuntukmencapai tujuannya. Selain itu agency lain yang digunakan adalah dengan mempercayai gizzard atau yakin dengan kemampuan dirinya sendiri dalam mencapai sebuah tujuan tertentu. Penggunaan senjata yang sederhana juga merupakan agency yang ditunjukkan dalam film ini.

Semua bentuk agency ini digambarkan dibeberapa adegan misalnya seperti, ketika Soren terbang melintasi api. Soren hanya mengandalkan gizzard dalam tubuhnya dan membawa cawan sebagai senjatanya. Penggambaran nilai kepahlawanan dalam film ini juga didukung oleh unsur purpose. Bentuk purpose yang ditampilkan dalam film ini adalah membasmi dan memerangi kejahatan demi menyelamatkan makhluk yang tertindas serta, mengembalikan kedamaian kerajaan burung hantu yang berada di pohon besar Ga'hoole seperti sediakala.

\section{Simpulan}

Berdasarkan hasil penelitian dan analisis dengan menggunakan pentad analysis Kenneth Burke pada film Legend Of Guardians: The Owls Of Ga'hoole, bisa ditarik kesimpulan bahwa film karya Zack Snyder ini mengandung pesan nilainilai kepahlawanan. Representasi atau perwujudan dari nilai-nilai kepahlawanan dalam film Legend Of Guardians: The Owls Of $\mathrm{Ga}^{\prime}$ hoole ini ditunjukkan dengan, penggambaran act yang selalu ditonjolkan dengan peperangan diantara tokohtokohnya untuk membasmi kejahatan dan mengembalikan kedamaian serta kesejahteraankelompoknya.Penggambaran nilai-nilai kepahlawanan juga didukung dengan scene yang menggunakan konsep low key lighting untuk memberikan kesan dramatis, menegangkan dan mencekam pada adegan peperangan yang dilakukan oleh tokoh-tokoh dalam film tersebut.

Selain itu nilai kepahlawanan juga digambarkan dengan penggunaan agent atau aktor yang mempunyai karakter gagah berani, pantang menyerah, rela berkorban, melindungi yang lemah, dan membela kebenaran yang diwakilkan melalui tokoh Soren, Digger, Twillight, Gylfie dan para Guardians. Karakter animasi yang dibuat pun menunjukkan wajah yang sederhana, bijaksana, lembut dan baik hati. Penggambaran nilai kepahlawanan juga didukung dengan agency yang digunakan oleh para tokoh dalam membasmi kejahatan. Bentuk agency ini ditampilkan dengan menggunakan kegiatan peperangan yang dilakukan oleh para tokoh untuk mencapai tujuannya. Selain itu agency lain adalah dengan mempercayai gizzard atau yakin dengan kemampuan dirinya sendiri dalam mencapai sebuah tujuan tertentu. Penggambaran nilai kepahlawanan juga didukung oleh unsur purpose yang ditampilkan dengan adegan sang tokoh yang sedang membasmi dan memerangi 
kejahatan demi menyelamatkan makhluk yang tertindas serta mengembalikan kedamaian kerajaan burung hantu yang berada di pohon besar Ga'hoole.

Selain mengusung pesan kepahlawanan, film Legend Of The Guardians: The Owls Of Ga'Hoole juga memberikan pesan kepada audiensnya bahwa dalam suatu kehidupan pasti ada yang baik dan ada yang buruk. Untuk mendapatkan sesuatu yang buruk kita harus bertarung dan menjatuhkan teman-teman kita. Sebaliknya, jika kita ingin mendapatkan suatu kebaikan maka kita harus berjuang dengan cara bekerjasama dan berteman dengan sesama demi mencapai tujuan tertentu.

Hasil penelitian ini juga menunjukkan bahwa nilai kepahlawanan bisa disampaikan melalui film, karena film mampu menyajikan realitas yang terjadi disekitarnya dengan perwakilan karakter dan didukung teknik-teknik sinematografi yang baik. Penggunaan teknologi yang canggih dan modern dalam memproduksi film merupakan salah satu pendukung bahwa film mampu menyampaikan makna dan pesan bagi audiensnya. Hal ini terbukti dengan pembuatan tokoh-tokoh animasi yang ada dalam film Legend Of Guardians: The Owls Of Ga'hoole. Melalui tokoh animasi tersebut, sutradara Zack Snyder mampu menggambarkan sifat kepahlawanan yang dimiliki oleh manusia kepada audiensnya. Target audiens dari film ini adalah anak-anak, maka sutradara mencoba menggambarkan nilai-nilai kepahlawanan tersebut dengan menggunakan animasi binatang yaitu burung hantu dengan harapan nantinya audiens bisa mengerti dan paham mengenai nilai maupun sifat kepahlawanan karakter dan nilai kepahlawanan.

\section{Daftar Pustaka}

Suparno, Basuki Agus, Adnan Hussein dkk. (2011). Pentad Analysis dalam Dramatisme Kenneth Burke dalam buku Mix Methodology dalam Penelitian Komunikasi, Yogyakarta: ASPIKOM.

Surata, Agus dan Andrianto, Tuhana Taufiq. (2003). Widya Mwat Yasa, Yogyakarta: Universitas Pembangunan Nasional "Veteran" Yogyakarta Press.

West, Richard and Turner, Lynn H. (2010). Pengantar Teori Komunikasi Analisis dan Aplikasi Jilid 2 Edisi 3. Jakarta: Salemba Humanika

http://bahasa.kemdiknas.go.id [diakases 26 Januari 2013]

http://raptorclubindonesia.or.id [diakses 8 Februari 2013]

Film Legend Of The Guardians: The Owls Of Ga'hoole, 2010, Warner Bros Picture 